\title{
The Honey Quality of Apis mellifera with Extrafloral Nectar in Lombok West Nusa Tenggara Indonesia
}

\author{
Erwan $^{*}$, Muhammad Harun ${ }^{1}$, Muhammad Muhsinin ${ }^{1}$ \\ ${ }^{1}$ Faculty of Animal Science, University of Mataram, Jalan Majapahit No. 62, Mataram 83125, Indonesia
}

\section{Article Info}

Received : March, 20th 2020

Revised : September, $15^{\text {th }} 2020$

Accepted: October, $6^{\text {th }} 2020$

\begin{abstract}
The purpose of the present study was to analyze Apis mellifera honey's quality given extrafloral nectar feed from Arenga pinnata sap and Cocus nucifera sap as stimulatory nutrition. The chemical compositions of honey, such as reducing sugar content, sucrose content, the acidity of honey, moisture content, and diastase enzyme activity, were measured. The comparison between A. mellifera honey's chemical compositions on Arenga pinnata sap and Cocus nucifera sap ware was analyzed using the student $t$-test (GraphPad Instant Statistical Program). The result from the analysis of reducing sugar content showed that the A. mellifera honey from Cocus nucifera sap $(73.69 \pm 0.21 \%)$ had a higher $(\mathrm{P}<0.05)$ than the Arenga pinnata sap $(60.15 \pm 2.13 \%)$. The significant differences $(\mathrm{P}<0.05)$ in the acidity of $A$.

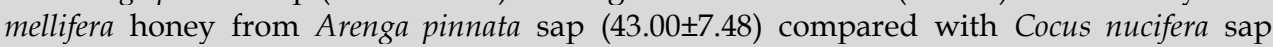
(22.00 \pm 2.14$)$. The sucrose content, moisture content, and diastase enzyme activity were not significant differences between the A. mellifera honey from Arenga pinnata sap compared with the $A$. mellifera honey from Cocus nucifera sap. In conclusion, the chemical compositions of A. mellifera honey with extrafloral nectar (Arenga pinnata sap and Cocus nucifera sap) are good quality and indicate that the honey falls under the limits of international standards. The A. mellifera honey from Cocus nucifera sap has a higher sugar reduction content and lower acidity than the A. mellifera honey from Arenga pinnata sap.
\end{abstract}

Keywords: Apis mellifera; extrafloral nectar; honey quality; chemical compositions of honey

Citation: $\quad$ Erwan., Harun, M., \& Muhsinin, M. (2020). The Honey Quality of Apis mellifera with Extrafloral Nectar in Lombok West Nusa Tenggara Indonesia. Journal of Science and Science Education (JoSSEd) 1(1): 1-7

\section{Introduction}

Honey is a natural product used by humans both as a food source and medical product from long periods to modern culture [1]. It applies to human diet health is due to its chemical composition. The honey composition is varied and linked to factors that directly affect its composition and quality, such as the bee species, floral source, and environmental and storage term [2]. Honey is a rich source of carbohydrates, making it widely used as a natural sweetener, as well as an important source of other minors constituents, which are more related to its biological properties such as polyphenols, carotenoids, minerals, proteins, free amino acid, enzymes and vitamins [3].
The world honey production and consumption are based on the product obtained from the species $A$. mellifera, whose producers are principally located in Europe and Asia. The A. mellifera, also called the Italian bee, is an important insect that produces high economic and ecological values for humans as a key pollinator of plants [4] and producer of bee products, including honey, royal jelly, pollen, propolis, and beeswax [5]. Each of these different bee products is becoming economically important and additionally, is known to have several potent bioactivities. Indeed, bee products have been used in traditional medicine throughout society. For instance, bee pollen is reported to boost energy and stamina [6], propolis to help maintain good health [7], royal jelly to support the immune system and increase energy [8], whilst honey, mainly used as a 
natural sweetener in every food culture, is also used traditionally used for the treatment of burns, sore throats and as an antiseptic [9]. More recent studies have found that several bee products have potential anticancer activity in vitro and in vivo [10].

According to [11], the average for honey production of A. mellifera is $25-40 \mathrm{~kg}$ per colony, $A$. dorsata is $50-80 \mathrm{~kg}$ per colony, A. florea is $0.2-0.9 \mathrm{~kg}$ per colony, A. cerana is $8-10 \mathrm{~kg}$ per colony, and stingless bee (Trigona $s p$ ) is $0.3-0.4 \mathrm{~kg}$ per colony per year. The honey production of A. mellifera can be increased by providing an additional feed of extrafloral nectar, which is the source of nectar outside the flower sector. One of the plants that can be an alternative to producing this nectar is palm (Arenga pinnata) and coconut (Cocos nucifera) plants. Both plants can release sweet liquid throughout the year called the extrafloral nectar or nira, obtained from the tap. The production sap or nira of Arenga pinnata per day per tree ranged from 8-12 liters [12] and 4-6 liters for Cocos nucifera sap [13]. These plants are widely available and grow well in the area of Lombok West Nusa Tenggara and spread throughout the region in Indonesia. Based on data from [14] the area of Arenga pinnata and Cocos nucifera plants in Lombok West Nusa Tenggara are $\pm 724 \mathrm{Ha}$ with \pm 112.665 trees and \pm 11.684 Ha with 2.763 .547 trees, respectively.

With the source of alternative feed is expected to produce honey of A. mellifera can be improved. Increased A. mellifera honey production must be followed by honey quality standards established by national and international agencies. Therefore, the present study aimed to analyze the quality of $A$. mellifera honey given extrafloral nectar feed from Arenga pinnata sap and Cocus nucifera sap as a stimulatory nutrition in Lombok West Nusa Tenggara, Indonesia.

\section{Materials and Method}

\section{Sample Collection}

A total of 16 A. mellifera honey samples, 8 for each honey type (Arenga pinnata and Cocus nucifera) were used in the study. The honey samples were collected from North Lombok district, West Nusa Tenggara Province, Indonesia.

\section{Reduced Sugar Content}

The estimation of reducing sugars was carried out using the using Luff Schoorl method. About $2 \mathrm{~g}$ of honey was weighed and diluted to $5 \mathrm{~mL}$ with $\mathrm{Pb}$ acetate $1 / 2$ base. Ten milliliters $(10 \mathrm{~mL})$ of solutions were transferred to a $500 \mathrm{~mL}$ Erlenmeyer flask containing 15 $\mathrm{mL}$ of water and $25 \mathrm{~mL}$ of Luff Schoorl's solution. The Erlenmeyer flask was heated to $2 \mathrm{~min}$ and $10 \mathrm{~mL}$ of KI
$30 \%$, and $25 \mathrm{~mL} \mathrm{H}_{2} \mathrm{SO}_{4} 25 \%$ was added, then titrated with a $0.1 \mathrm{~N} \mathrm{Na-thiosulfate} \mathrm{solution.} \mathrm{Make} \mathrm{a} \mathrm{blank}$ solution using $25 \mathrm{~mL}$ of water and $25 \mathrm{~mL}$ of Luff solution. The content of reducing sugar was calculated by the difference between the blank titration and the titration of the sample with the formula:

Reduced sugar level $=\frac{\text { mg sugar } x \text { dilution factor }}{m g \text { example }} \times 100 \%$

\section{Sucrose Content}

Inversion, sucrose content was determined by adding $5 \mathrm{~mL}$ of dilute $\mathrm{HCl} 0.25 \mathrm{M}, 50 \mathrm{~mL}$ of diluted honey solution, and water in a $100 \mathrm{~mL}$ volumetric flask. The solution was then warm in a water bath, cooled, and diluted to the mark. Finally, the sucrose content was obtained by calculating the sugar content difference after inversion and before inversion, then multiplied by 0.95 .

Sucrose $(\%)=(\%$ sugar after the inversion $-\%$ sugar reduction $) \times 0.95$
Sugar after the inversion $=\frac{m g \text { sugar } x \text { dilution factor }}{m g \text { example }} \times 100 \%$

\section{Acidity of honey}

Honey samples $(5 \mathrm{~g})$ were dissolved in $100 \mathrm{~mL}$ of volumetric flask. The filtrate $(25 \mathrm{~mL})$ was mixed with $50 \mathrm{~mL}$ of water, and 3-4 drops of phenolphthalein indicator were added. Titrate with $0.1 \mathrm{~N} \mathrm{NaOH}$ solution for $10 \mathrm{~s}$. The sample was titrated with $0.1 \mathrm{~N}$ $\mathrm{NaOH}$ solution at a rate of $5.0 \mathrm{~mL} / \mathrm{min}$. Titration was completed at $\mathrm{pH}=8.5$. The acid content in honey was calculated using the formula:

$$
\begin{aligned}
& \text { Acidity }(\mathrm{ml} \mathrm{N} \mathrm{NaOH} / \mathrm{kg})=\frac{a \times b}{c} \times 1000 \\
a= & \text { The volume of } \mathrm{NaOH} \text { in } \mathrm{mL} \\
b= & \text { Normality of } 0.1 \mathrm{~N} \mathrm{NaOH} \text { in } \mathrm{mL} \\
c= & \text { Sample weights in } \mathrm{g}
\end{aligned}
$$

\section{Moisture Content}

Honey samples $(3 \mathrm{~g})$ in the cup were put into the oven at $105^{\circ} \mathrm{C}$ for $4 \mathrm{~h}$ and cooled into the desiccator for $20 \mathrm{~min}$, then put again into the oven for one $\mathrm{h}$. The following formula calculated water content:

$$
\text { Moisture content }=\frac{X-Y}{Z} \times 100 \%
$$

$X=$ Weight sample before in oven (gr)

$Y=$ Weight sample after in oven (gr)

$Z=$ Weight sample of honey (gr)

\section{Diastase Enzyme Activity}

Diastase enzyme activity in the fresh honey was determined using the Phadebas method using the spectrophotometer. The first step of the Phadebas method was to prepare acetate buffer by dissolving $87 \mathrm{~g}$ 
of sodium acetate trihydrate in $400 \mathrm{~mL}$ of water. The $\mathrm{pH}$ of the solution was adjusted to 5.3, with 10.5 of glacial acetic acid. The solution was diluted to $500 \mathrm{~mL}$ with distilled water and stored in a glass bottle. Ten gram (10 g) of honey was weighed, quantitatively transferred to a $50 \mathrm{~mL}$ volumetric flask, and made up to volume with $5 \mathrm{~mL}$ of acetate buffer. Five milliliters of the sample was transferred to the test tube and placed in a water bath at $40^{\circ} \mathrm{C}$. At the same time, under the same conditions, the blank ( $5 \mathrm{ml}$ of acetate buffer) was heated in a water bath at $40{ }^{\circ} \mathrm{C}$. After $15 \mathrm{~min}, 1$ Phadebas tablet was added to the two solutions, stirred (approx. $10 \mathrm{~s}$ ), and placed back into the water bath at 40 ${ }^{\circ}$ C. After exactly $30 \mathrm{~min}, 1 \mathrm{~mL}$ of sodium hydroxide solution was added to interrupt the enzyme reaction.

The solutions were centrifuged in the next step (5 min; $1500 \mathrm{rpm}$ ), and the absorbance was measured at $620 \mathrm{~nm}$ against distilled water as the reference sample. The diastase number (DN) was calculated as 300 divided by $t_{x}$, required to reach the specified absorbance, 0.235 . The Schade unit is defined as that amount of enzyme that will convert $0.01 \mathrm{~g}$ of starch to the prescribed endpoint in one hour at $40^{\circ} \mathrm{C}$ under the test conditions.

\section{Honey Quality Standard}

As a reference to know the quality of honey required standards established by national and international agencies. Honey quality standards were presented in Table 1.

Table 2. The chemical compositions of A. mellifera honey from extrafloral nectar

\begin{tabular}{lll}
\hline Variable & Feed sources & \\
\cline { 2 - 3 } & Arenga pinnata sap $(\mathrm{n}=8)$ & Cocus nucifera sap $(\mathrm{n}=8)$ \\
\hline Reducing Sugar $(\%)$ & $60.15 \pm 2.13^{\mathrm{a}}$ & $73.69 \pm 0.21^{\mathrm{b}}$ \\
Sucrose (\%) & $4.40 \pm 2.04^{\mathrm{a}}$ & $4.21 \pm 0.83^{\mathrm{a}}$ \\
Acidity (NaOH/kg) & $43.00 \pm 7.48^{\mathrm{a}}$ & $22.00 \pm 2.14^{\mathrm{b}}$ \\
Moisture (\%) & $19.34 \pm 0.29^{\mathrm{a}}$ & $20.94 \pm 0.51^{\mathrm{a}}$ \\
Diastase Enzyme (Schade units) & $17.12 \pm 0.83^{\mathrm{a}}$ & $16.48 \pm 0.53^{\mathrm{a}}$ \\
\hline
\end{tabular}

n: Number of samples, the different superscript within the same row shows significant $(\mathrm{P}<0.05)$ difference

The reducing sugar content of $A$. mellifera honey from Cocus nucifera sap was significantly higher $(\mathrm{P}<0.05)$ than the A. mellifera honey from Arenga pinnata sap. The significant differences $(\mathrm{P}<0.05)$ in the acidity of A. mellifera honey from Arenga pinnata sap (43.00 \pm 7.48$)$

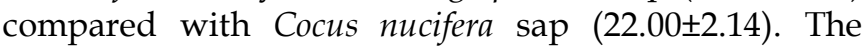
sucrose content, moisture content, and diastase enzyme activity were not significant differences between the $A$. mellifera honey from Arenga pinnata sap compared with the A. mellifera honey from Cocus nucifera sap.

The result of the analysis of reducing sugar content in A. mellifera honey from extrafloral nectar in accordance with CODEX STAN 12-1981 standard is not less than $60 \%(\mathrm{~g} / 100 \mathrm{~g})$, but lower than the SNI 3545:2013 standard for A. mellifera honey from Arenga
Table 1. Honey quality standard based on SNI 3545:2013 and CODEX STAN 12-1981

\begin{tabular}{|c|c|c|}
\hline $\begin{array}{l}\text { Constituent } \\
\text { Content }\end{array}$ & SNI 3545:2013 & $\begin{array}{l}\text { CODEX STAN 12- } \\
1981^{2}\end{array}$ \\
\hline $\begin{array}{l}\text { Moisture } \\
\text { (water) }\end{array}$ & Max. $22 \%(<22 \%)$ & Max. 20\% (<20\%) \\
\hline $\begin{array}{l}\text { Reducing } \\
\text { sugars }\end{array}$ & $\begin{array}{l}\text { Min. } 65 \mathrm{~g} / 100 \mathrm{~g}(> \\
65 \%)\end{array}$ & $\begin{array}{l}\text { Min. } 60 \mathrm{~g} / 100 \mathrm{~g}(> \\
60 \%)\end{array}$ \\
\hline Sucrose & $\begin{array}{l}\text { Max. } 5 \mathrm{~g} / 100 \mathrm{~g}(< \\
5 \%)\end{array}$ & Max. $5 \mathrm{~g} / 100 \mathrm{~g}(<5 \%)$ \\
\hline Free acidity & $\begin{array}{l}\text { Max. } 50 \mathrm{ml} \\
\mathrm{NaOH} / \mathrm{kg}\end{array}$ & Max. $50 \mathrm{mval} / \mathrm{kg}$ \\
\hline $\begin{array}{l}\text { Diastase } \\
\text { activity (DN) }\end{array}$ & $\begin{array}{l}\text { Min. } 3 \text { Schade } \\
\text { units }\end{array}$ & Min. 8 Schade units \\
\hline
\end{tabular}

\section{Statistical Analysis}

The data obtained in the study were analyzed statistically using student t-test (using GraphPad Instant Statistical Program). Differences between mean values were considered significant at values of $\mathrm{P}<0.05$

\section{Result and Discussion}

The chemical compositions of A. mellifera honey, such as reducing sugar content, sucrose content, the acidity of honey, moisture content, and diastase enzyme activity, were presented in Table 2.

pinnata sap. Bee honey's properties and compositions depend on its geographical floral origin, season, environmental factors, and treatment of beekeepers [17]. Bogdanov [18] found more than 22 sugars in honey; however, fructose and glucose are the major sugar content. Primary sugars that existed in honey are fructose and glucose, and in nectar honey, the fructose content should exceed that of glucose [19]. The sugar content of Arenga pinnata sap and Cocus nucifera sap is $10.5 \%$ and $10.9 \%$ respectively [20]. The high sugar content in bees feed can reduce honey sugar content [21]. Sugar reduction of honey results from the hydrolysis process by enzyme invertase of honeybees converts sucrose into glucose and fructose [22]. Bees convert the sugars in the nectar and add 
microorganisms and reduce the water content to prevent fermentation. The high and low sugar reduction in honey is influenced by the perfect or not hydrolysis process at the time of honey formation. Pourakbari [23] reported reducing sugar content in $A$. mellifera honey from Persimmon sap is $46.00 \pm 2.71 \%$, $63.89 \pm 0.25 \%$ from Acacia mangium and $61.17 \pm 0.17 \%$ from Ananas comosus [24] and 70.34 \pm 7.49 from multifloral [25].

The A. mellifera honey showed a sucrose content of $4.40 \pm 2.04 \%$ (Arenga pinnata sap) and $4.21 \pm 0.83 \%$ (Cocus nucifera sap), which is within the Indonesia national standard (SNI 3545:2013) and international parameters (CODEX STAN 12-1981) recommended for this honey $(<5 \%)$. The results show that the A. mellifera honey samples generally have higher sucrose content than Algerian honey (1.80 to $2.54 \%)$ [26]; [25] and comparatively similar to Malaysian honey (4.51\%) [24]. The significant carbohydrates of honey are glucose, fructose, and sucrose. They are frequently attended by complex sugars [27]. The rifest disaccharide in the plant's world is sucrose. In the nectar honey, its content normally does not outpace 3\% [28]. It is affected that mature nectar honey should not include more than 5\% of sucrose. According to [29], although honey contains an active sucrose separation enzyme (sucrase, glucosidase), honey's sucrose content never reaches zero. The sucrose contents acquired in this study are within the range of values reported for Argentine and Turkish [30], Venezuelan in Vit [31], American [32], and Pakistani in Zafar [19] honey.

The values obtained for the acidity of $A$. mellifera honey from extrafloral nectar were all within the limits of national and international standards (Max. $50 \mathrm{ml}$ $\mathrm{NaOH} / \mathrm{kg}$ ). Kowalski [33] reported the acidity values for honey having a range from $12.75 \pm 0.42$ to $62.61 \pm 0.88$ mval $/ \mathrm{kg}$. These results are similar to the results of other researchers [34]; [35]; [36]; [37]. The acidity is another parameter that plays an important role in honey quality and freshness. Although the acidic character is related to honey antimicrobial properties [1], high acidity levels can indicate sugar fermentation processes, thus affecting the organoleptic characteristics and quality of honey. The excessive acidity is the feature of fermented honey, and generally is the outcome of the several microorganisms development on their surface [38]. Honey acidity depends mainly on the type of material, maturity level, and season in which it was produced [39].

Moisture content is a necessary parameter of honey quality and necessary the amount of water provide in honey. In the present study, the percentage moisture content was between $19.34 \pm 0.29 \%$ (Arenga pinnata sap) and $20.94 \pm 0.51 \%$ (Cocus nucifera sap), which is under the limit of $\leq 22 \%$ set by the Indonesia national standard (SNI 3545:2013) for honey quality. Usually, the moisture contents for A. mellifera honey from extrafloral nectar in this study were relatively similar to those of other honey, such as Portuguese honey (15.9-17.2\%) [40], Anatolian honey (17.0-19.4\%) [41], Romanian honey (15.4-20.0\%) [42] and Indian honey (17.2-21.6\%) [43]. The moisture content provides in honey samples is important as it contributes to its capability to refuse fermentation and granulation through storage [44]. The moisture content was within the standard helps to encourage longer shelf life during storage [45]. Overall, the moisture content within the standard (SNI 3545:2013 and CODEX STAN 12-1981) in our honey samples shows their good storage capability and quality.

The diastase enzyme is the common name for the enzyme a-amylase. It is found in nectar and is also added by the honeybee during the collection and ripening of nectar. The diastase enzyme digests starch into simpler compounds. The diastase enzyme activity of A. mellifera honey obtained in this study was within the limits of minimal eight schade units specified by international norms and minimal three schade units for national norms. The results of the diastase enzyme activity of $A$. mellifera honey from extrafloral nectar samples showed that diastase enzyme activity between Arenga pinnata sap (17.12 \pm 0.83 Schade units) and Cocus nucifera sap (16.48 \pm 0.53 Schade units) were no significant differences $(\mathrm{P}>0.05)$. The floral origin of honey also influences its diastase content. For example, citrus and clover honey tend to contain less diastase enzyme [46]. Other factors may affect diastase values: the natural difference in $\mathrm{pH}$ among honey, nectar flow, and the bees' foraging patterns. Long storage at moderate temperatures and exposure to high temperatures will inactivate diastase in honey [47].

According to [48], honey's enzyme content may differ based on the age of the bees that vary in race, the nectar gathering time, the colony's physiological period, the quantity of nectar flow and its sugar content and pollen consumption. The diastase enzyme activity of A. mellifera honey with extrafloral nectar was higher than the previous report on Azerbaijan honey (9.69 Schade units) [39], Ethiopian honey (13.60 Schade units) [49], and comparatively similar to Venezuelan honey (16.13 Schade units) [31] and Algerian honey (15.10 Schade units) [50].

\section{Conclusion}

In this study, the values of quality parameters for A. mellifera honey from extrafloral nectar are good quality and coincide with those specified by the international honey regulations. The A. mellifera honey from Cocus nucifera sap has a higher sugar reduction 
content, and lower acidity compared the A. mellifera honey from Arenga pinnata sap. The results also reported extrafloral nectar as an alternative feed for honeybee in the topical area.

\section{Acknowledgments}

The authors wish to thank the Laboratory Staff of Laboratory of Agricultural Produce Processing Technology, Faculty of Agriculture, the University of Mataram, to carry out some aspects of this study.

\section{References}

[1] Alvarez-Suarez, J.M., Tulipani, S., Díaz, D., Estevez, Y., Romandini, S., Giampier,i F., Damiani, E., Astolfi, P., Bompadre, S., \& Battino, M. 2010. Antioxidant and antimicrobial capacity of several monofloral Cuban honeys and their correlation with color, polyphenol content, and other chemical compounds. Food Chem. Toxicol. 48 (8-9): 2490-2499. doi: 10.1016/j.fct.2010.06.021

[2] Gheldof, N., Wang, X.H., \& Engeseth, N.J. 2002. Identification and quantification of antioxidant components of honeys from various floral sources. J. Agric. Food. Chemistry. 50 (21): 5870-5877. doi: 10.1021/jf0256135

[3] Alvarez-Suarez, J.M, Gasparrini, M, ForbesHernández, T.Y, Mazzoni, L., \& Giampieri, F. 2014. The Composition and Biological Activity of Honey: A Focus on Manuka Honey. Foods. 3 (3): 420-432. doi: $10.3390 /$ foods 3030420

[4] Calderone, N.W. 2012. Insect pollinated crops, insect pollinators and US agriculture: trend analysis of aggregate data for the period 1992-2009. PLoS One. 7 (5): $\quad$ e37235. doi: https://doi.org/10.1371/journal.pone.0037235

[5] Biesaga, M., \& Pyrzynska, K. 2009. Liquid chromatography/tandem mass spectrometry studies of the phenolic compounds in honey. J. Chromatogr. A. 1216 (38): 6620-6626. doi: 10.1016/j.chroma.2009.07.066

[6] Feas, X., Vazquez-Tato, M.P., Estevinho, L., Seijas, J.A., \& Iglesias, A. 2012. Organic bee pollen: botanical origin, nutritional value, bioactive compaunds, antioxidant activity and microbiological quality. Molecules. 17 (7): 83598377. doi: https://doi.org/10.3390/molecules17078359

[7] Więckiewicz, W., Miernik, M., Więckiewicz, M., \& Morawiec, T. 2013. Does propolis help to maintain oral health?. Evid. Based. Complement. Alternat. Med. 2013 (1): 1-8. doi: 10.1155/2013/351062

[8] Terada, Y., Narukawa, M., \& Watanabe, T. 2011. Specific hydroxy fatty acids in royal jelly activate TRPA1. J Agric. Food. Chem. 59 (6): 2627-2635. doi: https:// doi.org/10.1021/jf1041646

[9] Iurlina, M.O., Saiz, AI., Fritz, R., \& Manrique, G.D. 2009. Major flavonoids of Argentinean honeys. Optimisation of the extraction method and analysis of their content in relationship to the geographical source of honeys. Food. Chem. 115 (3): 1141-1149. doi:

https:// doi.org/10.1016/j.foodchem.2009.01.003

[10] Premratanachai, P., \& Chanchao, C. 2014. Review of the anticancer activities of bee products. Asian Pac. J Trop. Biomed. 4 (5): 337-344. doi: 10.12980/ APJTB.4.2014C1262

[11]Das, T.K., \& Samajdar, T. 2013. Scientific method of honey production. Krishi vigyan kendra, Tura, India.

[12] Barlina, R., Karouw, S., \& Pasang P. 2006. Effect of fresh coconut husk on the quality of Arenga pinnata toddy and palm wine. J. Littri. 12 (4): 166-171. Doi: 10.21082/littri.v12n4.2006.\%p

[13] Supomo. 2007. Meningkatkan kesejahteraan pengrajin gula kelapa di Wilayah Kabupaten Purbalingga. Econ. J. Emerg. Mark. 12 (2): 149-162 (Id). doi: https:// doi.org/10.20885/ ejem.v12i2.513

[14] BPS. 2013. Portrait of West Nusa Tenggara agricultural business according to subsector. Badan Pusat Statistik, Mataram, Indonesia.

[15]SNI. 2013. Madu, Standar Nasional Indonesia, SNI 3545:2013. Badan Standardisasi Nasional: Jakarta.

[16] Codex Alimentarius. 2001. Revised codex standard for honey CODEX STAN 12-1981, Rev.1 (1987), Rev.2 (2001). http://www.codexalimentarius.net. Accessed 27 February 2018.

[17] Kaškonienè, V., Venskutonisa, P.R., \& Čeksterytèb, V. 2010. Carbohydrate composition and electrical conductivity of different origin honeys from Lithuania. LWT-Food. Sci Technol. 43 (5): 801-807. doi: https://doi.org/10.1016/j.lwt.2010.01.007

[18] Bogdanov, S., Rouff, K. \& Oddo, L.P. 2004. Physicochemical methods for the characterization of unifloral honey: a review. Apidologie. 35 (4): 275282. doi: https://doi.org/10.1051/apido:2004047

[19]Zafar, A., Safdar, M., Siddiqui, N., Mumtaz, A., Hameed, T., \& Sial, M.U. 2008. Chemical analysis and sensory evaluation of branded honey collected from Islamabad and Rawalpindi market. J Agric. Res. 21 (1): 86-91. 
[20] Tomomatsu, A., Itoh, T., Wijay, a C.H., Nasution, Z., Kumendong, J., \& Matsuyam, A. 1996. Chemical Constituents of Sugar-Containing Sap and Brown Sugar from Palm in Indonesia. Jpn J. Trop Agr. 40 (4): 175-181.

[21] Erwan. 2003. Pemanfaatan Nira Aren dan Nira Kelapa Serta Polen Aren Sebagai Pakan Lebah Untuk Meningkatkan Produksi Madu Apis cerana. Ph.D. dissertation, Bogor Agricultural University, Bogor, Indonesia.

[22] Sihombing, D.T.H. 1997. Ilmu Ternak Lebah Madu. Gadjah Mada University Press: Yogyakarta.

[23] Pourakbari, Y., Rezapour, A.K., \& Ghorbani, A. 2011. Effect of Persimmon Sap Nutrition on Sugars of Honey in Colony of Apis mellifera. Middle East J Sci Res. 10 (6): 794-797.

[24] Moniruzzaman, M., Khalil, M.I., Sulaiman, S.A., \& Gan, S.H. 2013. Physicochemical and antioxidant properties of Malaysian honeys produced by Apis cerana, Apis dorsata and Apis mellifera. BMC. Complement. Altern. Med. 13 (1): 43-54.

[25] Nweze, J.A., Okafor, J.I., Nweze, E.I., \& Nweze, J.E. 2017. Evaluation of physicochemical and antioxidant properties of two stingless beehoneys: a comparison with Apis mellifera honey from Nsukka, Nigeria. BMC. Res. Notes. 10 (1): 566-572. doi: 10.1186/s13104-017-2884-2

[26] Khalil, M.I., Moniruzzaman, M., Boukraâ, L., Benhanifia, M., Islam, M.A, Islam, M.N., Sulaiman, S.A., \& Gan, S.H. 2012. Physicochemical and Antioxidant Properties of Algerian Honey. Molecules. $17 \quad$ (9): 11199-11215. doi: 10.3390/molecules170911199

[27] Kamal, M.A., \& Klein, P. 2011. Determination of sugars in honey by liquid chromatography. Saudi. J $\begin{array}{lllll}\text { Biol. } & \text { Sci. } & 18 & \text { (1): } & \text { 17-21. }\end{array}$ doi: $10.1016 /$ j.sjbs.2010.09.003

[28] Rybak-Chmielewska, H., \& Szczęsna, T. 2003. Determination of saccharides in multifloral honey by means of HPLC. J Apic. Sci. 47 (2): 93-101.

[29] Buba, F., Gidado, A., \& Shugaba, A. 2013. Analysis of biochemical composition of honey samples from North-East Nigeria. Biochem. Anal. Biochem. 2 (3): 1-7. doi: 10.4172/2161-1009.1000139

[30] Cantarelli, M.A., Pellerano, R.G., Marchevsky, E.J., \& Camina. 2008. Quality of honey from Argentina: study of chemical composition and trace elements. J. Argentine. Chem. Soc. 96 (1-2): 33-41.

[31] Vit, P., Rodríguez-Malaver, A., Roubik, D.W., Moreno, E., Souza, B.A., Sancho, M.T., FernándezMuiño, M., Almeida-Anacleto, D., Marchini, L.C.,
Gil. F., González, C., Aguilera, G., \& Nieves, B. 2009. Expanded parameters to assess the quality of honey from Venezuelan bees (Apis mellifera). JAAS. 1 (3): 72-81.

[32] White, J.W., \& Doner, L.W. 1980. Honey composition and properties. Beekeeping in the United States Agriculture Handbook No. 335, Revised October 82-91.

[33] Kowalski, S., Łukasiewicz, M., \& Berski, W. 2013. Applicability of physico-chemical parameters of honey for identification of the botanical origin. Acta. Sci. Pol. Technol. Aliment. 12 (1): 51-59.

[34] Prica, N., Živkov-Baloš, M., Jakšić, S., Mihaljev, Z., Kartalović, B., Babić, J., \& Savić, S. 2014. Moisture and acidity as indicators of the quality of honey originating from vojvodina region. Arh. Vet. Med. 7 (2): 99-109. doi: https://doi.org/10.46784/eavm.v7i2.135

[35] Yadata. D. 2014. Detection of the Electrical Conductivity and Acidity of Honey from Different Areas of Tepi. Food Sci. Technol. 2 (5): 59-63. doi: 10.13189/fst.2014.020501

[36] Shobham, K.K., Chitluri., \& Nayar, J. 2017. PhysicoChemical Analysis of Some Commercial Honey Samples from Telangana. Indian J Nutri. 4 (1): 153157.

[37] Samarghandian, S., Farkhondeh, T., \& Samini, F. 2017. Honey and Health: A Review of Recent Clinical Research. Pharmacognosy. Res. 9 (2): 121127. doi: 10.4103/0974-8490.204647

[38] Olaitan, P.B., Adeleke, O.E., \& Ola, I.O. 2007. Honey: a reservoir for microorganisms and an inhibitory agent for microbes. Afr. Health. Sci. 7 (3): 159-165.

[39] Karimov, E., Xalilzad, Z., Hobbi, P., \& Alekperov, J. 2014. Quality evaluation of honey from the different region of azerbaijan. J Food. Chem. Nutr. 2 (2): 71-79.

[40] Gomes, S., Dias, L.G., Moreira, L.L., Rodrigues, P., \& Estevinho, L. 2010. Physicochemical, microbiological and antimicrobial properties of commercial honeys from Portugal. Food. Chem. $\begin{array}{llll}\text { Toxicol. } & 48 & \text { (2): } & 544-548 .\end{array}$ 10.1016/j.fct.2009.11.029

[41] Kücük, M., Kolayli, S., Karaoglu, S., Ulusoy, E., Baltaci, C., \& Candan, F. 2007. Biological activities and chemical composition of three honeys of different types from Anatolia. Food Chem. 100 (2): 526-534. doi: https:/ / doi.org/10.1016/j.foodchem.2005.10.010 
[42] Marghitas, L.A., Dezmirean, D.S., Pocol, C.B., Ilea, M., Bobis, O., \& Gergen, I. 2010. The development of a biochemical profile of acacia honey by identifying biochemical determinants of its quality. Not. Bot. Hort. Agrobot. Cluj. 38 (2): 84-90. doi: $10.15835 /$ nbha3824780

[43] Saxena, S., Gautam, S., \& Sharma, A. 2010. Physical, biochemical and antioxidant properties of some Indian honeys. Food Chem. 118 (2): 391-397. doi: https:/ / doi.org/10.1016/j.foodchem.2009.05.001

[44] Singh, N., \& Bath, P.K. (1997). Quality evaluation of different types of Indian honey. Food Chem. 58 (12): 129-133. doi: https://doi.org/10.1016/S03088146(96)00231-2

[45]Terrab, A., Gonzále, M., \& González, A. 2003. Characterisation of Moroccan unifloral honeys using multivariate analysis. Eur. Food. Res. Technol. 218 (1): 88-95.

[46] Assia, A., \& Ali, L. 2015. Enzymes activities, hydroxymethylfurfural content, and pollen spectrum of some Algerian honey. Afr. J. Agric. Res. 10 (7): 613-622. doi: https://doi.org/10.5897/AJAR2014. 9231

[47] Babacan, S., \& Rand, A.G. 2005. Purification of Amylase from Honey. J Food. Sci. 70 (6): 1625-1630. doi: https://doi.org/10.1111/j.13652621.2005.tb11439.x

[48] Oddo, L.P., Piazza, M.G., \& Pulcini, P. 1999. Invertase activityin honey. Apidologie. 30 (1): 57-65. doi: https://doi.org/10.1051/apido:19990107

[49] Belay, A., Haki, G.D., Birringer, M., Borck, H., Lee, Y.C., Kim, K.T., Baye, K., \& Melaku, S. 2017. Enzyme activity, amino acid profiles and hydroxymethylfurfural content in Ethiopian monofloral honey. J. Food Sci. Technol. 54 (9): 27692778. doi: 10.1007/s13197-017-2713-6

[50] Moussa, A., Noureddine, D., Saad, A., \& Douichene, S. 2012. The Relationship between Fructose, Glucose and Maltose Content with Diastase Number and Anti-Pseudomonal Activity of Natural Honey Combined with Potato Starch. Organic. Chem. Curr. Res. 1 (6): 1-5. 